BENM 2021

International Scientific and Practical Conference "Biotechnology, Ecology, Nature Management"

\title{
APPLICATION OF MODERN TECHNOLOGIES FOR PROCESSING PLANT WASTE
}

\author{
A. R. Nikolaev (a), A. N. Zhavnerov (b)*, B. K. Fedorov (c), A. P. Minaenko (d) \\ *Corresponding author
}

(a) K.G. Razumovsky Moscow State University of Technologies and Management (the First Cossack University), 73, Zemlyanoy Val str., Moscow, Russia

(b) K.G. Razumovsky Moscow State University of Technologies and Management (the First Cossack University), 73, Zemlyanoy Val str., Moscow, Russia, a.zhavnerov@mgutm.ru

(c) K.G. Razumovsky Moscow State University of Technologies and Management (the First Cossack University), 73, Zemlyanoy Val str., Moscow, Russia

(d) K.G. Razumovsky Moscow State University of Technologies and Management (the First Cossack University), 73, Zemlyanoy Val str., Moscow, Russia

\begin{abstract}
The easiest way to reduce the negative impact on the environment is to update and modernize equipment technologies, make changes in business planning that meet environmental standards. This is possible due to low-waste and waste-free production due to the economical import of all raw materials that are constantly produced and collected on farms. By reducing the amount of natural waste, air pollutants, water and wastewater use, a business can reduce its negative impact on the environment. For each industry, key production priorities depend on environmental changes in a holistic and quality manner, and after their implementation, environmental protection measures are developed and prices for them are calculated. The study revealed that bioconversion is the most promising way to utilize plants and plant waste. Along with the processing of the components of a conventional plant and grain, the technology makes it possible to reproduce and multiply the previous feeding properties of raw materials contaminated with pathogenic microflora, damaged by insects or partially destroyed due to improper storage.
\end{abstract}

2672-8575 (C) 2022 Published by European Publisher.

Keywords: Environmental protection measures, processing, technology and modernization, vegetable waste 


\section{Introduction}

The use of the bioconversion method is the most promising method for processing plant waste. The beginning of the bioconversion technology is as follows: primary materials containing a complex polysaccharide - pectin, cellulose, hemicellulose, undergo the preparation of complex enzymes, including pectinase, pemicellulase, and cellulose.

The following wastes can be used as primary raw materials:

1. Plant components of agricultural crops: planting and technical trees, baskets and sunflowers, flaxseed fire, corn, sweet potatoes, legumes, herbs and seedlings, grape waste, plantation tea, tobacco stem.

2. Waste from wheat production: bran, wheat harvest, and grain waste, mixing herbs, broken grains, dried wheat, sprouting, wild fruit seeds of the wrong size (Anosova, 2017).

- factory waste, winery waste and fruit waste: leather, fruit, damaged seeds, apples, grape waste, zucchini, coarse cuts, damaged zucchini, green waste, beets, potatoes, etc.

- waste from the sugar industry: beet powder, molasses, processed syrup, cake, beet bombs, beet tail.

- various brewing and alcoholic beverages industry.

- tea industry waste: tea dust, sweets, hairs, patiols.

- waste from key sectors of the oil industry: vegetable and vegetable waste.

- waste of fat and oil industry: sunflower, cotton.

- milk waste.

Consequently, all herbs and derivatives such as lignocellulose are in the process of bioconvention of microorganisms that feed on carbon and protein supplements (Lazarev et al., 2020).

Along with the processing of plants and components, the technology makes it possible to recover and re-feed food products that were previously supplied with basic raw materials contaminated with infected microflora, damaged by insects or partially damaged due to poor storage. (Voloshin, 2018)

\section{Purpose of the Study}

To evaluate the use of the bioconversion method as a method for processing plant waste with the use of a coal-protein additive.

\section{Research Methods}

When bioconversion is carried out in substandard areas, the microflora can cause diseases, serious infectious agents (brucellosis, tuberculosis, cholera, typhus, etc.). And protozoa also damage parasites. At the same time, the cost of food products from substandard raw materials after proper processing exceeds the cost of their analog food products by 1.4-1.8 times.

After the completion of the bioconvention process, the final product is delivered with a carbonprotein supplement (UBC), which contains 1.8-2.4 times more nutrients for feed than food grains, and contains other important and necessary ingredients. 
The peculiarity of the final products obtained by other methods of bioconverted microbial technology is that, as a rule, the primary raw materials for UBC additives are processed in an environment similar to the microflora of the first part of the esophagus, or by grinding. - "Cooking broken food" begins outside the esophagus (Bashkina, 2017).

\section{Findings}

Food supplement, UBC, very good value (22-26\% protein), easy to digest, functional value, as well as enzymes, vitamins and minerals.

Compared to the cost, the cost of production of 1 kilogram of high quality food products using the technology under consideration costs no more than 1 ruble, and in terms of nutritional value it exceeds grain by $1.8-2,4$ times.

Like traditional products, they made the use of a different biocomplex technology, meet standard dietary standards, and contain vital vitamins and bacteria with veterinarian, legal, and environmental benefits (Lugovoy, 2017).

The technology ensures the full-fledged work of the company from the beginning of the year, low requirements for the capacity of a large number of employees, and low cost.

Technologies do not pollute the environment and waste water.

The creation of a waste processing plant based on other technologies for the bioconvention of bacteria in food can be used for both individual and multifunctional solutions.

The most important means of energy transfer is the bioreactor, in which food waste is biotreated. The machines are simple and help to work with all raw materials and get various additives. A diagram of a plant for processing food microbes into food is shown in Figure 1 (Mironov, 2017).

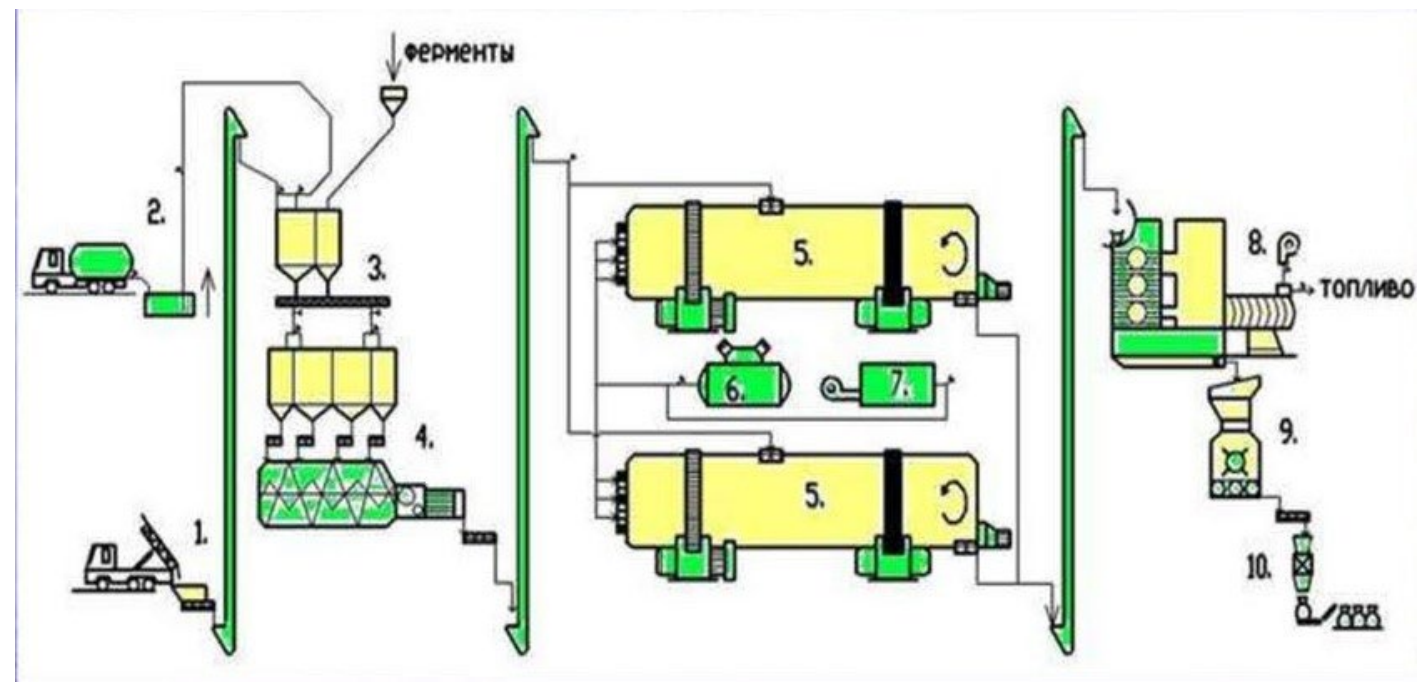

Figure 1. Technological scheme of microbiological processing of plant waste into feed

A wet mixture $(55 \%)$ of various TCWs is in the bio reactor. The process of bioconversion of bacteria in euryactors takes 4-6 days from the moment of packaging of raw materials (depending on the 
desired zo technical parameters in the final product). The answer is full addition - mostly carbon white (UBC). Now about drying to a temperature of $8-10 \%$, and then chopping.

Mixed foods are highly bioactive, and their digestion is characterized by high levels of digestion, but temporarily with higher levels of organism.

Unlike traditional high temperature heat exchangers, mixed products made using the biocomplex technology are significantly simplified without the use of oil (Anosova, 2017).

It is also interesting to receive organic fertilizers from animals, poultry, and crop production. Methods include mixing debris, dumping chicks, and catching water in the water; separation of biomass from waste water and solid ingredients by extracting water from biomass and collecting it; Difference between pollutants from water and solid and biothermal fermentation. Some of the water is contaminated by anaerobic fermentation with materials collected at a temperature of 35-40 degrees Celsius for 2-3 days. The main part is contaminated by aerobic fermentation in open pits at a temperature of $65-70{ }^{\circ} \mathrm{C}$. Contamination of the working area and bacteria from heat. It is well known that bacteria fight in heat and do not die at temperatures above 100 degrees Fahrenheit.

When preparing fertilizer from natural feces of animals, chickens and plants, garbage and bird manure, mixed with waste of crushed plants, contains one biomass. The resulting biomass is separated from the aqueous and solid components by separation. The aqueous part is contaminated with electrolytes and does not melt and after processing is processed by bacterial, aerobic and / or anaerobic fermentation. Large ozone-polluted area mixed with air and ultraviolet light. After boiling, some of the water spread over a large area. Wet biomass filled with a drum mixed with aerobic and / or anaerobic microflora, mixed and heated warm air, the enzymatic process in which it is produced. After enzymatic activity in the biomass, they leave the pile (Stepanova, 2017).

Due to the release of electrodes and electrolysis products in the middle: hydrogen radii, oxygen, hydroxyl groups, antimicrobial coins are destroyed, enzymes, protein systems, DNA are destroyed irreparably. The efficiency of suppressing microflora in the area of cells is $99.9 \%$.

Remove aquatic products from anaerobic (regular decomposition) chicken and debris: phosphine (PH3), phosphine (R-PH2), hydrogen sulfide (H2S), mercaptans (R-SH), ammonia (NH3). During oxidation, the product is transferred to phosphorus, sulfuric acid, nitric acid and derivatives instead of the cell anode.

The composition of mineral salts of industrial fertilizers includes acids obtained with neutral oxides and components of the aqueous region, especially ammonia, as well as non-toxic chemicals, acids, basic salts (Nikiforova, 2020).

The direct causes of the death of bacteria and viruses under the influence of the zone are localized damage to the plasma membrane of bacteria and changes in the main ingredients: protein oxide, interference with cell function.

The acids formed during oxidation form ammonium salts, which are less toxic than ammonia. Since ozone pollution is determined by direct contact with ozone, it is important, especially when it comes to the surface area of biomass, to increase the level of biomass pollution. 
Ultraviolet light at 205-310 $\mathrm{nm}$ has a significant bacterial effect (Bychkova et al., 2020). Viruses and bacteria in the form of plants are highly susceptible to ultraviolet rays. Mushrooms and protozoa are not easy. Most resistant spores of bacteria and fungi.

The death of bacteria on the surface is separated by $2 \mathrm{~m}$ from the UV source from $99.99 \%$ in 15 minutes at a rate of $50 \mathrm{~mJ} / \mathrm{cm} 2$ (Lugovoi, 2019).

Ultraviolet radiation travels in a straight line and acts primarily on nucleic acids, which are mutagenic and lethal to bacteria. Only tiny protoplasm was exposed to bacteria with bacterial antibodies.

In order to determine the maximum effect of surface contamination of large area parts, they are constantly modified. The latter is achieved by transferring a significant part of the screw technology when processing with an ozone-air mixture and shaking - in ultraviolet radiation.

Using conventional methods for preparing natural manure reduces the release of products that contaminate microbes that cause diseases in the environment, maintain hygiene and cleanliness in the production process, and provide a means to accelerate the production of industrial fertilizers (Smorodinskaya et al., 2021).

One of the simplest and cheapest ways to process wood and plant waste is to fertilize it in open areas (surface methods). Industrial fertilizers in a warehouse are usually produced in specially designed areas, the size and processing equipment are determined by the size of the waste. The technology for processing vegetables and vegetable waste on open sites is as follows. Waste collected in the urban sector is transported to the preparatory workshop, where the helicopter is disposed of. Wood waste is now mixed with the volume required to maintain a good, stored C: N ratio (Zyryanov, 2019)

Waste plants enter the site in a mixing chamber, from where they are conveyed by a conveyor belt to one of the mixing devices. In another mixing bunker, the prepared wood waste is transported by a forklift to the warehouse, which is also supplied with a conveyor belt. Waste is part of the weight to some extent: 1 part of the plant is waste and no more than 2.5 parts of wood with a shovel mixture.

In the mixing process, the waste turns into a mass of industrial fertilizers, which are transported by a forklift to the industrial fertilizer production site and placed on a pre-prepared line. After that, industrial fertilizers are covered with soil to prevent heat and moisture. To enhance the biothermal intensity, mass fertilization is applied to industrial manure when the pipes are connected to each other and placed under a base through which air is passed. When industrial fertilizers are opened, the heating of a large amount of natural energy during the cold is delayed or completely stopped, so optimal heat in the line must be maintained in practice.

When fertilizing, the manure tanks are cleaned by irrigation with water supplied to artillery or water supply tanks. An important part of technology is the control of body temperature and toxins (heat, temperature, oxygen content). In weighing management, they determine the benefits of a sustainable lifestyle as well as stopping the cultivation of fertilizers. Fertilization technology is provided.

On the basis of industrial fertilizers, a soil mixture has been developed, which is used in the green economy of the city. At the same time, industrial fertilizers and vegetable trees are processed: the cost of a part of household waste is reduced and complex industrial fertilizers for urban use are obtained. Production using this technology with a lower investment than the project will reduce the load on solid waste and improve the quality of the district and the city as a whole. 


\section{Conclusion}

The study revealed that bioconversion is the most promising way to utilize plants and plant waste. The essence of the bioconversion technology is as follows: raw materials containing complex polysaccharides - pectin, cellulose, hemicellulose, etc., are exposed to complex enzyme preparations containing pectinase, hemicellulose and cellulose.

Therefore, all raw materials and derived plants, as a source of lignocellulose, are available for biological microbiology to feed protein carbohydrates and feed additives (Ponomarev, et al., 2020).

Along with the processing of the components of a conventional plant and grain, the technology makes it possible to reproduce and multiply the previous feeding properties of raw materials contaminated with pathogenic microflora, damaged by insects or partially destroyed due to improper storage.

\section{References}

Anosova, E. B. (2017). Modern solutions for the processing of vegetable waste. Scientific and educational problems of civil protection, 4(35), 120.

Bashkina, T. A. (2017). Waste management innovation management. Economics and Business: Theory and Practice, 12,38 .

Bychkova, L. I., Nikiforov-Nikishin, D. L., Ponomarev, A. K., \& Bugaev, O. G. (2020). Evaluating the UV radiation effectiveness in industrial aquaculture. In IOP Conference Series: Earth and Environmental Science, 548, 042046. IOP Publishing. https://doi.org/10.1088/1755$1315 / 548 / 4 / 042046$

Lazarev, V. I., Lazareva, R. I., Shatokhin, M. V., \& Glebova, I. A. (2020, February). The Sources of Income and the Dynamics of Heavy Metals in the Soil of Different Agro-Ecosystems with Their Long-Term Agricultural Use. In IOP Conference Series: Materials Science and Engineering (Vol. 753, No. 6, p. 062030). IOP Publishing. https://doi.org/10.1088/1757-899X/753/6/062030

Lugovoy, Y. V. (2019). Thermal processing of wood waste. Bulletin of Science and Practice, 12(5), 2636. https://doi.org/10.33619/2414-2948/49/03

Mironov, S. Y. (2017). Technological directions for the processing of organic waste. Auditorium, 1(13), 42.

Nikiforova, Y. S. (2020). Alternative waste treatment methods. StudNet, 2, 378.

Ponomarev, A. K., Glebova, I. A., Gorbunov, O. V., \& Brezhnev, L. L. (2020, August). Aquaponics installation using soil in waste water from fish farms. In IOP Conference Series: Earth and Environmental Science (Vol. 548, No. 6, p. 062021). IOP Publishing. https://doi.org/10.1088/1755-1315/548/6/062021

Smorodinskaya, S. V., Bugaev, O. G., Gorbunov, A. V., \& Zhavnerov, A. N. (2021, March). Potentially dangerous to human pathogenic thermophilic microorganisms of fish in recirculation aquaculture systems. In IOP Conference Series: Earth and Environmental Science (Vol. 723, No. 4, p. 042074). IOP Publishing. https://doi.org/10.1088/1755-1315/723/4/042074

Stepanova, D. I. (2017). On the processing of organic waste. UEkS, 5(99), 11.

Voloshin, V. S. (2018). Prospects and opportunities for high-cycle waste processing. SHEE "Priazovskiy State Technical University", 36, 228. https://doi.org/10.31498/2225-6733.36.2018.143038

Zyryanov, M. A. (2019). Development of measures to increase the efficiency of processing industrial waste of plant origin. Forestry journal, 2(34), 171. https://doi.org/10.34220/issn.2222$7962 / 2019.2 / 18$ 